\title{
HEALTH ASPECTS OF CATTLE REARING ON PASTURE
}

\author{
J. WILLOMITZER and J. ŘÍHA
}

Veterinary Research Institute, 62132 Brno

Received February 28, 1983

\begin{abstract}
Willomitzer J., J. Ǩiha: Health Aspects of Cattle Rearing on Pasture. Acta vet. Brno, 52, 1983: $191-196$.

Comparison of pastured heifers with intensively reared animals showed significant differences in service period, calving interval, calving to first service interval and number of services per conception in favour of the former. The percentage of animals conceiving on first service was also higher among pastured than among non-pastured cattle (70.2 per cent as against 60.7 per cent). Disease incidence (except digestive disturbances, oophoritis and infectious keratitis and conjunctivitis) was found in higher percentages among non-pastured animals. Grazing in a pasture area with a shed as compared to the practice of grazing without using a shed played no substantial role in depressing morbidity but exerted a beneficial effect on milk yield. Grazing therefore meant not only a saving in fodder and utilization of pasture in diff icult-to-reach areas but was also an important factor in reducing morbidity of the animals and in improving their reproduction indicator values. The results imply the necessity of checks on the reproductive process in grazing and, primarily, intensively reared cattle to make full use of their reproductive potential.
\end{abstract}

Bohemian Pied and Black Pied Lowland cattle, reproductive cycle, milk yield, co-operation.

Heifer feeding on pasture is an important factor for further growth and fertility of heifers and milk production performance of cows (Szulc et al. 1979) and is also economic in terms of cost (Prokopowicz and Markiewicz 1979, Heinz 1981, a. o.).

Fascar and Fülessy (1980) studying veterinary economic aspects in pastured and housed animals found that where cattle were turned out on pasture, the costs of therapeutic and disinfection measures were reduced, number of services per conception was smaller and calving intervals were shorter.

On the other hand, pasture can also exert negative effects on animal health as evidenced by studies, e. g. on the persistence of Salmonella enteritidis on pastureland (Szabó 1976), the incidence of toxic plants and their effects on animals (Köhler et al. 1978, Pohlenz et al. 1980, Walker and Kirkland 1981), outbreaks of some diseases as a result of increased protein intake (Dankó et al. 1981), mass poisoning of animals grazing pasture high in nitrates (Galló and Papp 1981) apart from the possibility of increased dynamics of some parasitic diseases. The present study was designed to follow the health status of heifers not only during grazing but also after their transfer to intensive rearing barns up to the 2 nd or 3 rd parturition, giving at the same time attention to various indicators of reproduction related to this period of their lives.

\section{Materials and Methods}

Groups of grazing Bohemian Pied and Black Pied Lowland heifers totalling 1164 animals (368 of them kept on open range provided with a shed) and groups of confinement-reared heifers of the same breeds housed under intensive husbandry conditions (totalling 284 animals) were evaluated in the Moravian-Slovak borderland in 1978 to 1982 . The heifers were purchased by one animal enterprise at 7 to 11 months of age from co-operating enterprises, were turned out on pastu- 
re and then sold back to the co-operating enterprises during their 5th month of pregnancy. The pastured heifers were then followed up to the 2nd or 3rd calving during their stay in intensive rearing barns by evaluating the following data related to reproduction: percentage of successful first services, calving to first service interval, interval between subsequent services, number of services per conception, service period, calving interval and duration of pregnancy as well as disease incidence and milk yield.

The incidence of individual diseases during the grazing period and stay in intensive rearing barns was evaluated on the basis on veterinary service records and patho-anatomical findings obtained from the slaughter-house. Data on inseminations, conception, calving, parturition, milk yield, disease and culling were obtained from insemination cards and milk production cards at the co-operating enterprises and were further supplemented by information from the Regional Animal Breeding Administration. All these data were compared with those obtained for animals kept in the co-operating enterprises under intensive husbandry conditions without pasture.

The statistical significance of the results was assessed by Student's t-test. Analysis of between-groups variance was made by the Fischer-Snedecor F-test using a Programma 101 (Olivetti, Italy) calculating machine. In addition to analysis of variance, Duncan's test was used to specify the significance of the differences in selected cases.

\section{Results}

The heifers were either allowed to graze on open range without pens where their movement was directed only by the herdsman or were limited by solid pens (or less frequently by electric fences) to smaller areas where they had access to feed supplements and water and could move freely without being directed by the herdsman. They were turned out to graze as soon as the soil humidity content and the plant stand allowed it and as a rule remained at pasture from May to October. The size of pen- or fence-limited areas was chosen so as to provide grazing for not more than 5 to 6 days. Continuous 24-hour grazing without return to sheds was practiced in all pasture areas except one where use was occasionally made of a shed for night.

Observations for grazing habits showed that the animals grazed for 6 to 7 hours a day, mostly in the morning, then at about 15 hours and after 19 hours. They consumed normally about $1.5 \mathrm{~kg}$ granulated feed per animal per day but considerably more when the weather conditions were bad so that the means for individual groups and years ranged from 2.3 to $4.0 \mathrm{~kg}$ granulated feed (25 to $37 \%$ concentrates) per animal per day. The grazing period in individual years was 129 to 172 days. Pasture plant intake in individual years ranged from 16.9 to $35.5 \mathrm{~kg}$ per animal per day. Average daily gains in body mass were 0.32 to $0.59 \mathrm{~kg}$. Comparison of mean body mass values at the beginning of the grazing season with total gains in individual herds showed, for the most part, the operation of Robertson's law (cited according to Koubek and Hajič 1971), i. e. growth rate decreased as body mass approached maximum attainable values. Total gains in body mass were lowest $(60.7$ to $61.1 \mathrm{~kg}$ ) in heifers whose body mass range at the beginning of the grazing period was 263.6 to $282.5 \mathrm{~kg}$, intermediate $(75.4$ to $88.0 \mathrm{~kg})$ in heifers with an initial body mass range of 203.5 to $247.6 \mathrm{~kg}$ and highest $(91.7$ to $98.8 \mathrm{~kg}$ ) in animals with an initial body mass range of 194.7 to $203.5 \mathrm{~kg}$.

Adoption of a number of preventive measures ensured good protection against infectious diseases during the grazing period, except for the incidence of infectious keratitis and conjunctivitis which in some years appeared, on average, in 1 to 7 per cent of animals in individual herds. Vaccination with Kérabov (produced by Département Vétérinaire de l'Institut Mérieux, Lyon) was tested in 1980 but proved ineffective.

Comparison of disease incidence in individual groups of animals (Table 1) 
Table 1

Disease incidence in intensively reared and pastured heifers and dairy cows

\begin{tabular}{|c|c|c|c|c|}
\hline \multirow{2}{*}{ Diagnosis } & \multicolumn{4}{|c|}{ Per cent diseased } \\
\hline & A & $\mathbf{B}$ & $\mathrm{Ba}$ & $\mathrm{Bb}$ \\
\hline Respiratory disease & 1.1 & 0.5 & - & 0.9 \\
\hline Liver disease & 2.5 & 0.5 & 0.9 & - \\
\hline Kidney disease & 1.1 & 0.5 & 0.9 & - \\
\hline Digestive disturbances & 3.2 & 3.6 & 3.4 & 3.8 \\
\hline Metabolic disorders & 2.5 & 0.5 & 0.9 & - \\
\hline Traumatic inflammation of the first three & & & & \\
\hline compartments of the stomach & 2.8 & 1.8 & 2.5 & 0.9 \\
\hline Diseases of the limbs & 6.0 & 1.3 & 1.7 & 0.9 \\
\hline Prolapse of the vagina & 0.4 & 0.9 & 1.7 & - \\
\hline Suppurative inflammation of the uterus & 37.0 & 32.1 & 33.9 & 30.2 \\
\hline Prolapse of the uterus & 1.4 & 0.9 & 0.9 & 0.9 \\
\hline Ovarian cysts & 3.2 & 2.2 & 2.5 & 1.9 \\
\hline Oophoritis & - & 0.9 & 0.9 & 0.9 \\
\hline Uterine cysts & 0.7 & - & - & - \\
\hline Recumbency after calving & 3.2 & - & - & - \\
\hline Injury to the birth canal + sepsis & 8.1 & 4.0 & 4.2 & 3.8 \\
\hline Retained placenta & 10.6 & 2.7 & 2.5 & 2.8 \\
\hline Monsters & - & 1.3 & 1.7 & 0.9 \\
\hline Sterility & 20.4 & 11.2 & 11.9 & 10.4 \\
\hline Complicated parturition & 7.0 & 6.3 & 9.3 & 2.8 \\
\hline Udder anomalies & 2.5 & 0.5 & - & 0.9 \\
\hline Mastitis & 6.7 & 3.1 & 3.4 & 2.8 \\
\hline Infectious keratitis and conjunctivitis & - & 7.0 & 6.0 & 4.0 \\
\hline
\end{tabular}

\footnotetext{
A $=$ intensively reared animals.

$\mathrm{B}=$ pastured animals.

$\mathrm{Ba}=$ animals pastured in an area provided with a shed.

$\mathrm{Bb}=$ animals pastured in an area without a shed.
}

Table 2

Reasons for culling intensively reared and pastured heifers and dairy cows

\begin{tabular}{|c|c|c|c|c|}
\hline \multirow{2}{*}{ Diagnosis } & \multicolumn{4}{|c|}{ Culls $(\%)$} \\
\hline & A & B & $\mathrm{Ba}$ & $\mathrm{Bb}$ \\
\hline Respiratory disease & 0.7 & 0.5 & - & 0.9 \\
\hline Liver disease & 1.8 & 0.5 & 0.9 & - \\
\hline Kidney disease & 1.1 & 0.5 & 0.9 & - \\
\hline Digestive disturbances & 0.4 & 3.6 & $3 \cdot 4$ & 3.8 \\
\hline Metabolic disorders & 1.8 & 0.5 & 0.9 & - \\
\hline Traumatic inflammation of the first three & & & & \\
\hline compartments of the stomach & 1.4 & 1.8 & 2.5 & 0.9 \\
\hline Diseases of the limbs & 4.6 & 1.3 & 1.7 & 0.9 \\
\hline Prolapse of the vagina & 0.4 & 0.9 & 1.7 & - \\
\hline Suppurative inflammation of the uterus & 0.7 & 1.8 & 2.5 & 0.9 \\
\hline Ovarian cysts & 0.7 & 0.5 & - & 0.9 \\
\hline Recumbency after calving & 2.5 & - & - & - \\
\hline In jury to the birth canal + sepsis & 6.0 & 3.6 & 4.2 & 2.8 \\
\hline Sterility & 20.4 & 11.2 & 11.9 & 10.4 \\
\hline Abortion & 0.7 & 1.8 & 2.5 & 0.9 \\
\hline Complicated parturition & 2.8 & 2.3 & 2.5 & 1.9 \\
\hline Mastitis & 1.4 & 0.9 & 1.7 & - \\
\hline Low milk production performance & 5.3 & 2.7 & 0.5 & 4.7 \\
\hline Injury during transport & 0.4 & - & - & - \\
\hline Total $\%$ culled & 51.4 & 33.5 & 38.1 & 28.3 \\
\hline
\end{tabular}

A $=$ intensively reared animals.

$\mathrm{B}=$ pastured animals.

$\mathrm{Ba}=$ animals pastured in an area provided with a shed.

$\mathrm{Bb}=$ animals pastured in an area without a shed. 
shows that, except for digestive disturbances, cophoritis, prolapse of the vagina, birth of monsters and infectious keratitis and conjunctivitis, diseases were more frequent in intensively reared animals than in those grazed in a pasture area with or without a shed. The fact that some disease incidence values were higher in animals pastured in areas provided with a shed suggests that this rearing practice played no major role in depressing morbidity.

A surprising finding was the relatively high culling rate $(51.4 \%)$ in intensively reared animals as compared to that found in pastured animals $(33.5 \%$ ) (Table 2). The highest per cent culls were because of digestive disturbances (higher in pastured animals), disease of the limbs, recumbency after calving, sterility and low milk production performance (culls higher in intensively reared animals). There were no major differences in culling rates as to whether heifers were grazed in an area with or without a shed.

Table 3

Values of reproduction indicators and milk production of intensively reared and pastured heifers and dairy cows

\begin{tabular}{|c|c|c|c|c|}
\hline \multirow{2}{*}{ Index } & \multirow{2}{*}{$\begin{array}{l}\text { Intensively } \\
\text { reared animals }\end{array}$} & \multirow{2}{*}{$\begin{array}{l}\text { All pastured } \\
\text { animals }\end{array}$} & \multicolumn{2}{|c|}{ Pasture area } \\
\hline & & & with a shed & without a shed \\
\hline Age at first conception (days) & $\begin{aligned} & 560 \\
\pm & 108.0\end{aligned}$ & $\begin{array}{c}567 \\
\pm \quad 80.9\end{array}$ & $\begin{array}{l}595 \\
\pm \quad 81.7\end{array}$ & $\begin{array}{c}539 \\
\pm \quad 69.4\end{array}$ \\
\hline$\%$ animals conceiving on first service & 60.7 & 70.2 & 67.2 & 73.7 \\
\hline Interval between subsequent services (days) & $\begin{array}{r}53.3 \\
+41.0\end{array}$ & $\begin{array}{r}59.5 \\
\pm 37.3\end{array}$ & $\begin{array}{r}64.2 \\
\pm 39.8\end{array}$ & $\begin{array}{r}54.9 \\
\pm 33.9\end{array}$ \\
\hline No. services per conception & $\begin{array}{r}1.70 \\
\pm 0.88\end{array}$ & $\begin{array}{r}1.41 \\
\pm 0.50\end{array}$ & $\begin{array}{r}1.44 \\
\pm 0.46\end{array}$ & $\begin{array}{r}1.38 \\
\pm 0.53\end{array}$ \\
\hline Calving to first service interval (days) & $\begin{array}{r}86.3 \\
\pm 46.6\end{array}$ & $\begin{array}{r}77.5 \\
\pm 34.0\end{array}$ & $\begin{array}{r}81.4 \\
\pm 37.9\end{array}$ & $\begin{array}{r}73.6 \\
\pm 29.0\end{array}$ \\
\hline Service period (days) & $\begin{array}{r}124.8 \\
\pm 78.2\end{array}$ & $\begin{array}{r}108.3 \\
\pm 65.5\end{array}$ & $\begin{array}{r}118.7 \\
-175.1\end{array}$ & $\begin{array}{r}97.9 \\
+50.7\end{array}$ \\
\hline Calving period (days) & $\begin{array}{r}406.8 \\
\pm 76.8\end{array}$ & $\begin{array}{r}386.3 \\
\pm 52.8\end{array}$ & $\begin{array}{r}391.4 \\
+54.3\end{array}$ & $\begin{array}{r}381.2 \\
\pm 50.7\end{array}$ \\
\hline Duration of pregnancy (days) & $\begin{array}{r}281.3 \\
\pm 11.6\end{array}$ & $\begin{array}{r}282.4 \\
\pm 8.3\end{array}$ & $\begin{array}{r}281.6 \\
\pm 7.6\end{array}$ & $\begin{array}{l}283.2 \\
\pm 9.9\end{array}$ \\
\hline Milk yield (litres) & $\begin{array}{l}3.411 \\
\pm 982\end{array}$ & $\begin{array}{l}3.304 \\
\pm 890\end{array}$ & $\begin{array}{l}3.640 \\
\pm 819\end{array}$ & $\begin{array}{r}2.968 \\
\pm 935\end{array}$ \\
\hline
\end{tabular}

Grazing had also favourable effects on the values of reproduction indicators under study and on milk yield (Table 3 ). Significant $(P<0.01)$ differences between pastured and non-pastured animals were found in service period, calving interval and calving to first service interval; a highly significant $(P<0.001)$ difference was found in number of services per conception. It should also be noted that the percentage of animals conceiving on first service was higher among pastured than among non-pastured cattle $(70.2 \%$ as against $60.7 \%)$. Comparison of milk production performance in animals pastured in areas with or without a shed showed a highly significant $(P<0.001)$ difference in favour of the former.

During our study it became clear that sheds in grazing areas have both advantages and disadvantages. Heifers turned out to graze in submontane and mountain areas might have been affected by adverse weather conditions during the early and late portions of the grazing period. In this case the shed gave partial protect- 
ion against bad weather, which resulted in subsequent higher milk yield. Another advantage was the possibility of restraining animals in pens for examination and treatment. The disadvantage was that heifers leaving the shed in the morning and returning to it for night lingered around the shed, thus promoting the spread of parasitic diseases.

\section{Discussion}

Significant differences in reproduction indicator values between pastured and non-pastured animals reported in this study emphasize the importance of grazing in keeping with observations made by other writers (Věžník et al. 1979, Fascar and Fülessy 1980, Müller 1981). It should be added that the mean annual rainfall in the area under study, with its peaks in June, July and August, favoured the plant growth in pastures. Mean temperatures in these months were also favourable to the vegetation. Soil tests confirmed the adequacy of the soil for growing high-quality grasses.

Chemical and phytocoenological examination showed that the pasture plants were fresh but low in nitrogen and organically bound minerals, and supplementary feeding was therefore necessary. The supplementary feeds were chosen so as to make up for possible qualitative and quantitative deficiencies of the daily rations as determined by previous examination. Since in this way the ration was made practically the same in all the groups of grazing animals under study, the differences in their health status could not be influenced by feed intake.

\section{Zdravotní problematika při pastevním odchovu skotu}

Byl prokázán statisticky významný rozdíl ve prospěch zvířat odchovaných na pastvě u service periody, mezidobí, intervalu a inseminačního indexu. Procento zabřeznutí při I. inseminaci bylo taktéž vyšší u zviřat odchovaných na pastvě $(70,2)$ než u zvírat bez pastvy $(60,7)$. Výskyt onemocnění (kromě poruch trávicího ústrojí, zánětu vaječníků a infekčního zánětu rohovky a spojivek) byl zjištěn ve vyšším procentu u zvířat bez pastvy. Odchov zviřat na pastvě se salaší neměl podstatný vliv na snižování nemocnosti, avšak projevil se jako pozitivní činitel při jejich užitkovosti. Pastva znamenala tedy nejen úsporu píce a využití travních porostů v těžko dostupných lokalitách, ale byla též významným činitelem při snižování nemocnosti zvířat a při zlepšení jejich reprodukčních ukazatelů. Dosažené výsledky dokládají nutnost kontroly reprodukčního procesu jak $\mathrm{v}$ pastevních podmínkách, tak především $\mathrm{v}$ chovech skotu $\mathrm{k}$ efektivnímu využití jejich reprodukčního potenciálu.

\section{Санитарно-гигиеническая проблематика при выгонном разведении крупного рогатого скота}

Была установлена статистическая значимая доля в пользу животных, разводимы на пастбище в сервис-периоде, в промежуточном периоде, интервале и индексе осеменения. Процент забеременения при 1 осеменении был также выше у животных, разводимых выгонным способом $(70,2)$ чем у живогных без выгона $(60,7)$. Процент заболеваний (помимо недомоганий пищевари- 
тельного тракта, воспаления яичников и инфекционного воспаления роговиџы и соединительной оболочки) был выше у животных без выгона. Разведение животных на пастбище с шалашом не оказывало существенного влияния на понижение заболеваемости, однако положительно отразилось на продуктивности. Пастбище связано не только с экономией кормов и использованием травостоев в трудно доступной местности, но оно стало важным фактором при понижении заболеваемости животных и улучшении показателей их воспроизводства.

Достигнутые результаты являются доказательством необходимости контроля процесса воспроизводства не только в выгонных условиях, но и при разведении крупного рогатого скота, направленном на эФФективное использование их потенциала воспроизводства.

\section{References}

DANKÓ, G. - SZERAFIN, J. - SZILÁGYI, M.: Legelöváltoztatással kapcsolatos betegségek hazai hereford szarvasmarha-állományokban. Magy. Állatorv. Lap., 36, 1981; 153-160.

FASCAR, I. - FÜLESSY, E.: Kötetlen tartástechnológiájú, szakosított tejtermelö tehenészeti telepek állategészégügyi ökonomiájáról, különös tekintettel a legeltetésre. Magy. Állatorv. Lap., 35, 1980; 606-609.

GALLÓ, F. - PAPP, J.: Tömeges nitrát-nitritmérgezés legelön tartott allatokon. Magy. Állatorv. Lap., 36, 1981: $762-764$.

HEINZ, S.: Ökonomische Aspekte der Weidehaltung. Mh. VetMed., 36, $1981 ; 161-164$.

KOUBEK, K. - HAJIČ, F.: Nalezení kritických úseků ve vývoji a stanovení optimální křivky růstu jalovic odchovávaných na horách. Acta Scient., 3, 1971; 1-66.

KÖHLER, H. - LIBISELLER, R. - SCHMID, S. - SWOBODA, R.: Zur Kalzinose der Rinder in Österreich. VII. Untersuchungen zur Bedeutung der Aufwuchsstadien sowie der Gewinnung (Silage, Heu) von Goldhafer (Trisetum flavescens) für die Entstehung der Kalzinose. Zbl. VetMed., A, 25, 1978: 617-633.

MÜLLER, M.: Veterinärmedizinische Aspekte der Weidehaltung in der Rinderproduktion. Mh. VetMed., 36, 1981: 511-513.

POHLENZ, J. - LÚTHY, J. - MINDER, H. P. - BIVETI, A.: Enzootische Leberzirrhose beim Rind, verursacht durch Pyrrolizidinalkaloide nach Aufnahme von Senecio alpinus (Alpenkreuzkraut). Schweizer Arch. Tierheilk., 122, 1980; 183-193.

PROKOPOWICZ, J. - MARKIEWICZ, M.: Wybrane zagadnienia ekonomiczne zywienia pastwiskowego i alkierzowego duzych stad krów mlecznych. Przegl. hodowl., 47, 1979: 13-14.

SZABÓ, J.: Adatok a Salmonella enteritidis életbenmaradásáról a legelö növényzetén öntözés után. Modellkísérlet. Magy. Állatorv. Lap., 31, 1976; 161-164.

SZULC, T. - SZYC, M. - OLAK, J.: Choroby u cielat i ich wplyw na pozniejszy wrost jalovic i uzytkowosc krów mlecznych. Med. weter., 35, 1979; 616-619.

VĚŽNÍK, Z. et al.: Soustava veterinární péče $\mathrm{v}$ chovu skotu pro podmínky integrované velkovýroby. Project report. Veterinary Research Institute Brno, 1979, 64 p.

WALKER, K. H. - KIRKLAND, P. D.: Senecio lautus toxicity in cattle. Aust. vet. J., 57, $1981 ; 1-7$. 